MIRJANA VOJVODA

Institute of Archaeology,

Belgrade, Serbia

mirjana.vojvoda@gmail.com
904:737.1.032.044"652"

94(398)"00/02"

321.18(37):929

COBISS.SR-ID 228047628

Original research article

Received: March $4^{\text {th }} 2016$

Accepted: June $20^{\text {th }} 2016$

\title{
CONCEPT OF PROVIDENTIA DEORUM WITHIN THE IMPERIAL CULT AND PROPAGANDA ON ROMAN IMPERIAL COINS DURING THE PRINCIPATE
}

\begin{abstract}
Ever since the beginning of the Principate, after establishing the imperial cult, propaganda was also developed and adjusted to support this cult. Reverse images on coins expressed different aspects of the imperial cult, among others the concept of providentia deorum. Starting during Domitian's reign, then during Trajan's, in Hadrian's time, the concept of providentia deourum is clearly focused, expressing multiple connections of the emperor with the gods. Not only does the emperor enjoy divine protection, first of all from Jupiter, but even more importantly, he was chosen by him to rule. An image of the current emperor was created, who became emperor by Jupiter's prudence alone. This fact, hidden in the multiple meanings of the aforementioned images of emperors and Jupiter, was clearly shown on Hadrian's mints, in the scene depicting Jupiter's eagle, which brings and hands over a sceptre to Hadrian with the legend providentia deorum.
\end{abstract}

KEYWORDS: ROMAN EMPIRE, COINAGE, REVERSE IMAGES, PROPAGANDA, IMPERIAL CULT, PROVIDENTIA DEORUM.

The institution of the imperial cult, as known during the Principate, originated in the 1 st century B.C., but the breaking point in its development is represented by the deification of Caesar, in 42 B.C. ${ }^{1}$ From one point of view, in the 1 st century B.C., the problem of the legitimacy of military a commander's position, not institutionalised in a republican sense, ${ }^{2}$ relied on the developing personality cult. Caesar's tendency to stress the origin of the Julii from Venus was actually one of the methods he used to justify his position. How-

1 The article results from the project: Viminacium, Roman city and military camp - research of material and non- material culture of inhabitants by using the modern technologies of remote detection, geophysics, GIS, digitalization and $3 D$ visualization (no 47018), funded by The Ministry of Education, Science and Technological Development of the Republic of Serbia.

2 The Triumvirate was not an institutional body, but was created with the initiative of men in power supported by the military, with the excuse that the state needed order. ever, at the same time, it represented the beginning of the imperial cult. ${ }^{3}$ Caesar transformed into a living symbol of all of the virtues familiar to the Romans - he was a triumphator, liberator and pater patriae. The connection between the invincible military commander, political leader of the

3 Whenever possible, Caesar highlighted the origin of the Julii from Venus, starting with the famous laudative speech at the deathbed of his aunt Iulia, in 68 B.C. (Suet. Caes. 6). He would express the idea about the divine origin of the Julii through his speeches and deeds. After Pompeius' defeat, he started wearing red boots and toga picta in public, as a symbol of the connection to the kings of Alba Longa, whose establishment is connected to Ascanius, the son of Aeneas (Dio Cass. XLIII.43.2). During his lifetime, he was given numerous honours (a golden chair in the Senate, permission to ride a horse in Rome, statues and prayers were dedicated to him, he had his special priests' collegia, the month of July was given his name and, finally, his image appeared on coins) and, as Suetonius notes: "bigger honours than a man is allowed to achieve"( $\mathrm{Su}$ et. Caes. 76). Similar comments are encountered from Plutarch (Plut. Caes. 57). 
state and the gods was established, at the same time leading towards the establishment of a monarchical autocracy. After that, Octavian wisely established a new governmental structure - the Principate - within the framework of the already existing republican institutions. ${ }^{4}$ During his reign, the imperial cult was gradually established and, in time, it was institutionalised.

After Caesar's apotheosis, by a decision of the Senate, a decree was issued that people would be allowed to respect his Genius, in the same way they had always respected the Genius of their house masters (pater familias). At the same time, it was made possible for Octavian to become divi filius, who, in 29 B.C., dedicated the temple to the divine Julius (divus Iulius) at the place where Caesar was cremated. ${ }^{5}$ The next important moment in the development of the imperial cult was in 27 B.C., when Octavian allegedly handed over power to the senate and to the people of Rome. This "resignation" was undoubtedly formal, accompanied by senators' pleas for him to retain power. At the same meeting of the Senate, Octavian received a series of authorities, securing him supreme power. Besides this, he also received the honorary title of Augustus, ${ }^{6}$ and a decision was made to place a laurel wreath on his house door and a golden shield, or a shield of virtues (clipeus virtutis), in the Senate, bearing an inscription that praises his basic virtues: courage, gentleness, equity and piety (virtus, clementia, iustitia, pietas) (Res gestae VI. 34). During the Principate, these four virtues would represent the sum of qualities

4 The main republican institutions, the magistratures and the Senate, still existed, although the Roman state was made a monarchy from Augustus' time, under the authority of the first man in the state (primus inter pares).

5 After Caesar's deification and the following civil war, Octavian often pointed to his position as son of divine Caesar (divi filius), according to which he had legitimate right to revenge for his father's murder. In 38 A.D., in connection to this, he appears on sidus Iulium coins, also portraits of Octavian and Caesar with the inscriptions IMP DIVI IVLI F or DIVOS IVLIVS DIVI F (RRC I, p. 535, no. 534/1, 2, T. LXIII.19,20).

6 Ever since then, his new name is Imperator Caesar divi filius Augustus (Kienast 2010, 63). to be possessed by a "good" princeps. As propaganda, these virtues were skilfully incorporated in accordance with tradition, tending to be restored by Augustus. ${ }^{7}$

During his lifetime, throughout the Empire, Augustus was respected as the most important person of the state, who also enjoyed great religious respect. Testimony is given in a paragraph from "Life of Augustus" by Nicolaus of Damascus: "Men gave him this name in view of his claim to honour; and, scattered over islands and continents, through city and tribe, they revere him by building temples and by sacrificing to him, thus requiting him for his great virtue and acts of kindness toward themselves." In all of the provinces, temples were built dedicated to Roma and Augustus' genius, following the tradition of the former decision of the Senate regarding the respect of Augustus' genius. By using religion, politics and propaganda, Augustus managed to establish an imperial cult, through which he achieved the recognition of his divine nature after death. By modifying the concept of Genius and accepting honour to be paid to his own Genius, he established a way for the public to unofficially worship his possible divine nature. At the same time he also relied strongly on the model of the cult of Alexander of Macedon, which led to the gradual development of the imperial cult as a unique Roman institution. At the same time, within the imperial cult established in such a way, the concept of providentia was developed. Writers and poets of Augustus' time highlight recognition of divine will in the fact that they were given such a great rescuer and ruler (Charlesworth 1936: 109).

7 About the choice of exactly these virtues, $c f$. Wallace-Hadrill 1981, 300-307); for development of visual images of virtues on coinage from Vespasianus to Alexander Severus, $c f$. Noreña 2001, 146-168.

8 ,Men gave him this name in view of his claim to honor; and, scattered over islands and continents, through city and tribe, they revere him by building temples and by sacrificing to him, thus requiting him for his great virtue and acts of kindness toward themselves." (FGhH 90, f. 125). About sacrifice in Roman imperial cult cf. Price 1984, 2843. 


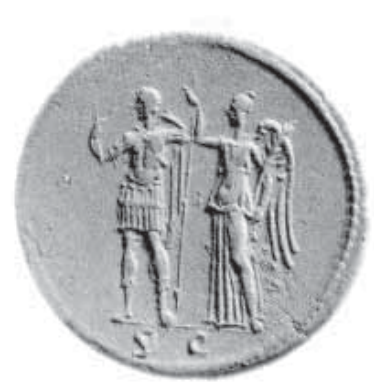

Fig. 1 BMC II, Pl. 75.8

On 19th August 14 A.D., Augustus died. He was cremated on the Field of Mars and buried in his family tomb (Suet. Augustus 100). After the funeral, an eyewitness appeared who swore he had seen Augustus' apotheosis, making an association with Romulus. ${ }^{9}$ Soon after that, on September 17 th, he was officially deified by a decision of the Senate, followed by consecration, performed by Tiberius (Chalupa 2008: 202, ref. 19-20). The practice of deifying a deceased emperor was established and it was continuously developed during the Principate, also spreading to members of the imperial family. From Augustus to Constantine, 36 emperors and 27 members of imperial families were deified (Price 1984: 57). ${ }^{10}$

For the purpose of spreading the imperial cult, propaganda was skilfully used, manifested through different media: public monuments and inscriptions, altars and temples honouring emperors, their priestly collegia and festivals, writers engaged in state service etc. However, emperors reached the high level of general political propaganda, even the segment connected to the imperial cult, by minting coins. Coins had an advantage compared to all the other means of propaganda, basically because of their role as a mean of payment, which made them an inevitable

9 The eye-witness was Numerius Atticus, senator and a former praetor, who was given one million sestertii from Livia for this testimony (Dio Cass. 56.46.2). Tradition says that the legendary king and the founder of Rome, Romulus, rose to heaven and ever since then, the Romans pray to him as Quirinus (Plut. Romulus 28.1-3).

10 For the development of the emperors' divinisation process and certain problems that are encountered in modern science related to this, cf. Chalupa 2008, 201-207 with literature. part of every-day life and were, thus, required in high quantities. Among other things, the emperors' power depended on the belief of his subjects that he personally possessed gifts or talents essential for their own good, but which were beyond the reach of ordinary mortals. The belief was that these powers actually come from the outside and did not originate in usual human nature (Wallace-Hadrill 1981: 298, ref. 2).

One of the aspects of propaganda, incorporated into reverse images on coins, is a motif with the legend PROVIDENTIA DEORVM. The users were given a message that rule and power in the state was for the benefit of all of its citizens, given to the emperor through the will and prophecy of the gods, primarily Jupiter. From this basic propaganda message, with the concept of providentia deorum, its connection with the problem of inheritance in the Principate also emerged. Basically, there were no rules for inheriting the throne. Attempts by current principes to seek out legitimate ways of naming their heirs went in two directions: either by choosing from among their family members or through adoption. The wrong choice could lead to civil war and to an ever increasing interference by the army in the process of choosing principes, which would become the rule during the $3^{\text {rd }}$ century A.D, after the Severan dynasty. The best solution seems to have been adoption, successful from Nerva to Marc Aurel (Vojvoda, Tapavički-Ilić 2012: 303-304). Popularising the chosen heir was an important part of the imperial propaganda at all levels, in order to secure a peaceful change of rule.

In developing the concept of providentia deorum on coins and its role in the imperial cult, one should certainly mention the Domitian sestertius, from 86 (Fig. 1). On the reverse, the emperor is shown in his military uniform, holding Jupiter's lightning bolt in his right hand and a spear in his left; behind him, there is Victoria, holding a palm branch and coronating Domitian. ${ }^{11}$ The palm in Victoria's hand, as an symbol of victory, corre-

11 BMC II, p. 381, no. 381; Pl. 75.8; RIC II, p. 195, no. 322. Inscription is missing, except $\mathrm{S} \mathrm{C}$ in ex. 

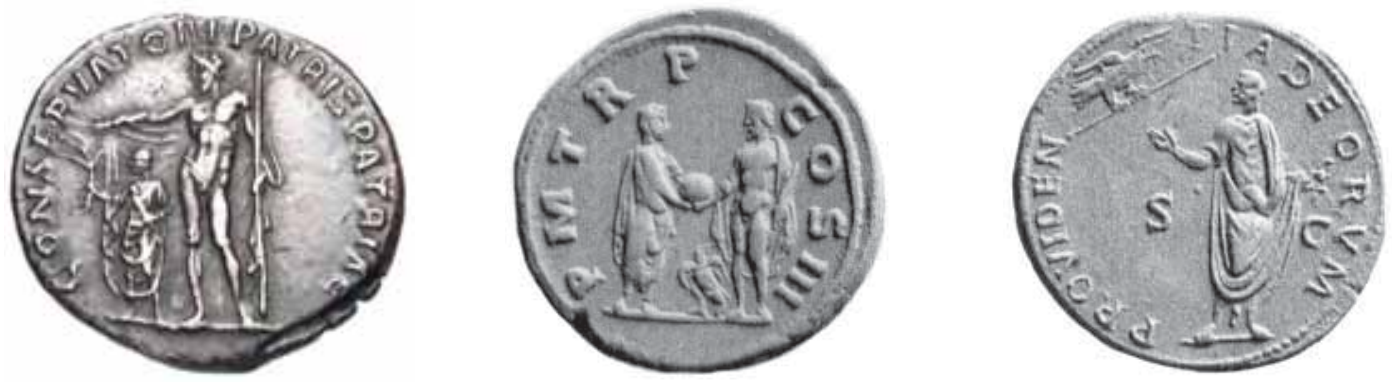

Fig. 2 http://www.wildwinds.com/coins/ric/trajan/RIC_0249_denarius.jpg

Fig. 3 BMC III, Pl. 51.8;

Fig.4 BMC III, P1. 79.3

sponds to the divine lightning bolt in Domitian's hand, connecting him with Jupiter. Even more importantly, this motif is connected to the central theme of the Principate as a system: the emperor is Jupiter's representative on Earth and his rule expresses the providentia of the supreme deity (Hannestad, 1986, 141). The propaganda message of this reverse motif was intended to depict a divine ruler, addressed as dominus et deus noster (Suet. Domit. 13). In other words, the motif expresses the self-apotheosis of Domitian, as suggested by Carradice (Carradice, 1993: 170, ref. 22).

The first adoption in the Principate brought certain changes in depicting the inheritance of the throne on coins. In order to pacify and satisfy the army, Nerva (Dio Cass. LXVIII. 3-4) adopted Trajan, but did not mint any motives that would indicate the position of the chosen heir. ${ }^{12}$ However, during the first year of independent rule, Trajan himself minted aurei and denarii depicting his reception of the globe from Nerva (RIC II: 246, no. 28). The accompanying legend of PROVID (in the sense of providentia augusti) indicated Nerva's clever choice of heir. Providentia august $i$ was related to the emperor's care in a broad sense, from choosing his heir to supplying citizens and represented his foresight for the welfare of the state and his subjects. The connection with Jupiter was specific (especially on motifs when the emperor was depicted as being protected by Jupiter's

12 It is the period from Trajan's adoption at the end of October 97 B.C. to Nerva's death, on $27^{\text {th }}$ (?) January 98 B.C. (Martin, 1982, 227-228). lightning bolt), indicating not only under whose protection the emperor stood, but also by whom he was chosen to rule. In that sense, motifs on Trajan's mints are peculiar, showing Jupiter's giant figure, holding a lightning bolt in his outstretched arm, above a much smaller figure of Trajan, with the legend CONSERVATORI PATRIS PATRIAE (RIC II: 261, no. 249) (Fig. 2). Already in Hadrian's mints, this original expression of stratification was explicitly shown in the scene depicting Jupiter handing over the globe to the emperor.

The circumstances of the election of Trajan's heir are not completely clear, with some of them remaining as pure hypotheses. Although Trajan highly respected Hadrian's military capabilities, he did not officially adopt him and proclaim him as his heir, the reasons for which remain unclear. ${ }^{13}$ Seriously ill, Trajan died on his way from Syria to Rome. After hearing the news, the eastern legions under Hadrian's command proclaimed him as emperor (CAH XI: 299-300). Only after that, the news reached Rome that Trajan had proclaimed Hadrian as his heir on his deathbed. This caused rumours similar to those after Augustus' death (Tacitus Ann. I.7; SHA, Vita Hadriani IV. 8-10). Hadrian enjoyed great sympathy from Trajan's wife Plotina and the praefectus pretoriae, Acilius Atianus and, according to Dio Cassius, he was

13 Seriously ill, Trajan began his journey to Rome, leaving Hadrian as the commander of the greatest army in the East (he had eleven legions and a great number of auxiliary troops under his command), basically giving him the second position in the empire. 
not adopted at all, but received his power because of their engagement (Dio Cass. LXIX 1. 1-2). ${ }^{14}$ Hadrian's early emissions are related to adoption and inheriting the throne: Trajan hands the globe over to Hadrian (RIC II: 338, no. 2) or Hadrian and Trajan shaking hands, with the legend ADOPTIO (RIC II: 339, no. 3). The symbolic reception of global rule (empire), depicted with the placing of a globe into Hadrian's hands, as well as with the motive of the dextrarum iunctio gesture, highlighting the legend ADOPTIO, clearly indicates that the inheritance of the throne was secured by virtue of Trajan's providentia augusti ${ }^{15}$

The development of the providentia augusti theme started during Nerva's reign. During Hadrian's reign, it received new associations, such as the idea of providentia deorum. This represents the development of a new propaganda idea, which was adjusted to the needs of the current circumstances (Martin 1982: 266). On aurei, minted between 119 and 122 A.D., Hadrian is shown, wearing a toga, receiving the globe with both hands from Jupiter, with an eagle next to Jupiter's feet (BMC III: 269, no. 51.8, Pl. 51.8; RIC II: 353, no. 109) (Fig. 3). At the same time, for the first time, there is a scene with the legend PROVIDENTIA DEORVM, representing a unique motive of this kind during the Principate. Hadrian is shown wearing a toga, looking to the skies, towards an eagle that flies to him, bringing a sceptre in its beak (BMC III: 417, no. 1203, Pl. 79.3; RIC II: 415, no. 589) (Fig. 4). Hadrian is shown as a princeps, in a civilian aspect, his right arm outstretched in a ges-

14 It was clear that coins should be minted as soon as possible, on which Hadrian was named augustus and heir. An aureus was minted with Trajan's bust on the obverse and Hadrian's bust on the reverse, with the legend HADRIANO TRAIANO CAESARI (RIC II, 338, n. 1). According to this, the conclusion could be that Hadrian was a Caesar, but not an August and that the coins were minted during Trajan's lifetime. It is possible that it was minted after Trajan's death, but before the news reached Rome (RIC II, 338 , ref. 1).

15 Dextrarum iunctio is a gesture of great ritual symbolism, first of all indicating the concept of Fides, uniting two depicted people in an unbreakable bond whilst, at the same time, announcing concordance (Concordia). ture of receiving the sceptre from Jupiter's eagle. Although the reception itself is not performed in this scene, Hadrian's outstretched arm leaves no doubt that this will occur (Brilliant 1963: 130). In this way, Hadrian's right to inherit the throne is expressed - he becomes emperor in accordance with Jupiter's divine decision of providentia.

In order to complete the propaganda idea of Hadrian as the rightful heir, a series of aurei and denarii was minted, depicting the emperor as a genius of the "golden age", standing in an oval frame, holding in his hand a symbol of eternal renovation (in this case, inheriting) and Fenix on a globe, with the legend SAEC AVR (RIC II: 356 , no. 136). In this case, the legend saeculum aureum, usually hidden behind phrases such as $f e$ licitas temporum or saeculi felicitas, is explicitly stated and represents the only example of its kind in Roman mints (BMC III, CXXXI). Hadrian is represented as a new ring in the unbroken chain of world rulers. Propaganda expressed in such a way, strictly related to the throne inheritance, is certainly connected with the aforementioned unclear situation connected to the change on the throne (Martin 1982: 279). ${ }^{16}$

After that, until the end of the Principate, different motifs would be depicted with the legend PROVIDENTIA DEORVM, but always as allegories, with an image of a personification, but never as clear as with Hadrian. At the beginning of his rule, Antonine Pius, adopted by Hadrian, ${ }^{17}$ minted aurei with the legend PROVIDENTIAE DEORVM and the motif of a winged lightning bolt (RIC III: 35, no. 80) (Fig. 5). Although depicted discretely, the idea clearly indicates that Antonine Pius was given power by the will of Jupiter. The model was adopted and in early, so-called "programmed" series, it became usual to promote the power of the current

16 It seems that speculation mentioned in written sources was not without reason.

17 After the death of Lucius Aelius, his first chosen heir, Hadrian, claimed that he would adopt Antoninus Pius, under the condition that he adopted Marc Aurel (at that time engaged to the daughter of the late Aelius) and Lucius Verus (Aelius' son) (SHA, Vita Hadriani XXIV.1). 

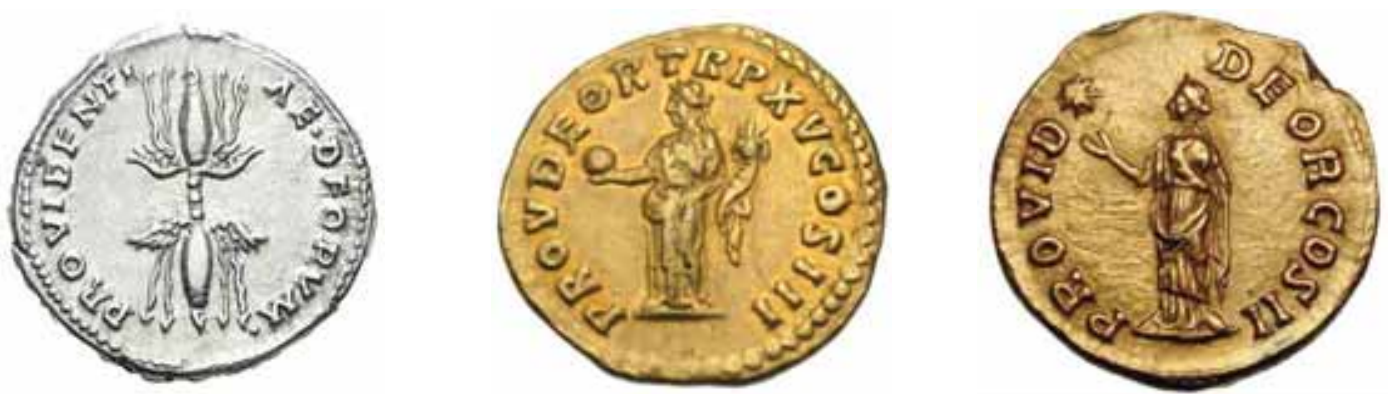

Fig. 5 http://www.coinarchives.com/a/results.php?results=100\&search=providentiae

Fig. 6 http://www.wildwinds.com/coins/ric/marcus_aurelius/RIC_0020.jpg;

Fig. 7 http://www.wildwinds.com/coins/ric/pertinax/RIC_0011a,Aureus_2.jpg

princeps. Apart from representing the will of his predecessor, it also represented Jupiter's wish to make him the ruler of the world.

In the early Augustan series of Marc Aurel and Lucius Veraus, from 161 A.D, on aurei and denarii, the legend PROV DEOR appears with the motif of Providentia, sitting and holding a patera or standing, holding a globe and a cornucopia (RIC III: 215, nos. 18-25; 251, nos. 460-466) (Fig. 6). The same motif would be repeated by Marc Aurel during the celebration of the decennalia in 171 A.D. (RIC III: 296, no. 1045). In Commodus' early series from 180 A.D, the same legend with a variant appears on an image - Providentia holds a stick above the globe and a sceptre in the other hand (RIC III: 402, no. 301). During his short reign, Pertinax minted aurei, denarii and sestertii with the legend PROVID DEOR/PROVIDENTIAE DEORVM (RIC IV: 1, 8, nos. 10-11; 11, nos. 29-31) (Fig. 7). Here, one encounters an exceptional image - Providentia stands with her hands lifted towards a large star. In this case, the star probably represents the emperor as caelo demissus, sent from heaven to the earth as salvation (RIC IV: 1, 4, ref. 2).

The motif of Providentia holding a stick above the globe and a sceptre in the other hand, as well as a variant in which the personification holds a cornucopia instead of a stick, was later most commonly repeated with the legend providentia deorum and they are encountered in the mints of Geta, Caracalla, Macrinus, Elagabalus, Alexander Severus, Balbinus and Pupienus, and later still with Tacitus. In the period from Gordian III to Aurelianus, it is interesting to note that there were no mints with the legend providentia deorum, with types bearing the legend providentia augusti being much more frequent. This is a consequence of the historical circumstances of the time, in which many emperors changed on the throne, there were many usurpations and serious external difficulties. In Aurelianus' time, there was a change regarding patronage of the supreme deity. Actually, by that time, in the early mints, it was common to mint motifs of Jupiter Conservator, but during Aurelianus' reign and his introduction of the Sol Invictus cult, the most common reverse legends became Oriens Aug and Soli Invicto. Eventually, this influenced changes in motifs with the legend providentia deorum. A personification is depicted (Providentia or Fides) holding two insignia, standing across Sol and holding a globe (npr. RIC V: 1, 268, no. 19; RIC V: 1, 281, no. 152) (Fig. 8). Pacification is highlighted, achieved in the East, under the patronate of Sol Invictus. Tacitus repeats Aurelianus' motif with Sol, but also mints other motifs, returning to the more traditional values. Besides the most common, earlier motif of a personification with a stick and a cornucopia, there is a motif with the emperor holding an insignia and receiving the globe from Jupiter (RIC V: 1, 331, no. 54). Aurelianus' model of depicting Providentia with Sol is encountered during the Principate only with the mints of Florianus and Probus (RIC V: 1, 359, no. 110; RIC V: 2, 496, no. 380).

To modern scholars, compared to other histor- 


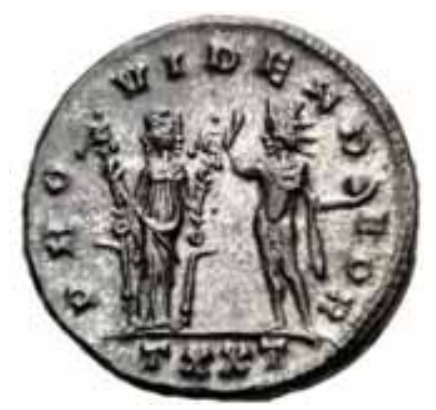

Fig. 8 http://www.wildwinds.com/coins/ric/aurelian/ RIC_0152_T.jpg

ical sources, Roman imperial coinage offers great possibilities, primarily due to the huge number of preserved pieces. The advantage of this mass evidence is to study the symbolic system created with the iconography of imperial mints. Firstly, with the frequency of reverse types in different periods and by comparing them, one can gain insight into the function of such a symbolic system. At the same time, new possibilities are opened for reading the "visual language" of the Roman imperial coinage (Noreña 2001: 164). Starting during Domitian's reign, then during Trajan's, in Hadrian's time, the providentia deourum concept is clearly focused, expressing multiple connections of the emperor with the gods. Not only does emperor enjoy divine protection, first of all from Jupiter, but even more importantly, he was chosen by him to rule. The image of a current emperor was created, who was given power by the will of Jupiter himself. This fact, hidden in the multiple meanings of the connections between the emperor and Jupiter, is explicitly shown on Hadrian's coins, in the scene where Jupiter's eagle brings and hands over the sceptre to the emperor, with the legend providentia deorum. The same meaning is given to the scenes in the mintings from Hadrian to Probus, in which emperors receive the globe from Jupiter, as a symbol of world rule.

During the $3^{\text {rd }}$ century, with the ever increasing problems in external and internal political, military and economy spheres, changes occur in the priorities of the imperial propaganda. The propaganda of solid and responsible emperors, especially during the 2 nd century, did not consist of promises concerning a hazy future, but represented a reminder of actual achievements. As time passed by, beliefs and emotions were focused on a single person, on the virtus and providentia of the emperor, which threatened to produce an attitude of an overgrown addiction and underdeveloped initiative, too huge an expectation for a single person to solve a problem. In the 3 rd century, emperors faced pressure from external enemies, internal political problems, a difficult economic situation and a moral crisis. As the situation grew more difficult, the propaganda, sober and based on facts during the $2^{\text {nd }}$ century, became louder and louder, in order to settle the uneasiness, but without much success. Coinage proclaimed loyalty and concordance in the army, at exactly the same time as there were constant mutinies and rebellions among the soldiers. In the period when Rome was faltering, there was still an insistence to depict the emperor as eternal and invincible.

With the stabilisation of the state in Aurelianus' time, there were changes regarding the patronage of the supreme deity. The introduction of the cult of Sol Invictus was reflected in the motifs of reverse images with the legend PROVIDENTIA DEORVM, on which there was a personification of a military kind, with insignias, accompanied by Sol Invictus. Historic circumstances led to changes in all the social spheres, including religion. The propaganda of the imperial cult was always adjusted to it and within it was also the concept of providentia deorum. 


\section{BIBLIOGRAPHY}

\section{BMC II - Mattingly, H. 1930}

Coins of the Roman Empire in the British Museum, Vol. II, Vespasian to Domitian, London: British Museum.

\section{BMC II - Mattingly, H. 1936}

Coins of the Roman Empire in the British Museum, Vol. II, Nerva to Hadrian, London: British Museum.

\section{Brilliant, R. 1963}

Gesture and Rank in Roman Art, New Haven Connecticut: Academy of Art and Sciences.

CAH XI - Bowman, A. K., Garnsey, P. and Rathbone, D. (eds.) 2000

The Cambridge Ancient History, Vol. XI, The High Empire, A.D. 70-192 (2nd ed.), Cambridge: Cambridge University Press.

\section{Carradice, I. 1993}

Coin Types and Roman History: The Example of Domitian, in: Essays in Honour of Robert Carson and Keneth Jenkins: 161-175.

\section{Chalupa, A. 2008}

How Did Roman Emperors Become Gods? Various Concepts of Imperial Apotheosis, Anodos. Studies of the Ancient World 6-7 (20062007): 201-207.

\section{Charlesworth M. P. 1936}

Providentia and Aeternitas, Harvard Theological Review 29 (1936): 107-132.

\section{DioCass. - Cassius, Dio.1924}

Roman History, Translated by E. Cary, Loeb Classical Library. Cambridge Mass., London: Harvard University Press.
Suet. - Svetoni, C. T. 1978

Dvanaest rimskih careva. Prevod Stjepan Hosu.

Rijeka: Naprijed.

Plut. Caes. - Plutarh, 1988

Usporedni životopisi III, Zagreb: August Cesarec.

Plut. Caes. - Plutarh, 1988

Usporedniživotopisi I, Zagreb: AugustCesarec.

Res gestae -1924

Velleius Paterculus and Res Gestae Divi Augusti, Translated by Frederick W. Shipley, Loeb Classical Library, Cambridge Mass., London: Harvard University Press.

FGhH - Fragments of the Greek Historians; Jacoby, F. 1923

Die Fragmente der griechischen Historiker, (trans. By) C. M. Hall, Berlin: Weidmann.

\section{Hannestad, N. 1986}

Roman Art and Imperial Policy, Højbjerg: Jutland Archaeological Society.

\section{Kienast, D. 2010}

Römische Kaisertabelle, 4. Auflage, Darmstadt: Wissenschaftliche Buchgesellschaft.

\section{Martin, J.-P. 1982}

Providentiadeorum. Recherches sur certains aspects religieux du pouvoir impérial romain, Rome: École Française de Rome.

\section{Noreña, C. F. 2001}

The Communication of the Emperor's Virtues, The Journal of Roman Studies, Vol. 91 (2001): 146-168.

\section{Price, S .R. F. 1984}

Ritualsand Power: The Roman Imperial Cult in Asia Minor. Cambridge:

Cambridge UniversityPress. 
RIC II - Mattingly H.and Sydenham E. A. 1962

The Roman Imperial Coinage, Vol. II, Vespasianto Hadrian, London: Spink \& Son Ltd.

RIC III - Mattingly H.and Sydenham E. A. 1930 (repr. 1962)

The Roman Imperial Coinage, III, Antoninus Pius to Commodus, London: Spink \& Son Ltd.

RIC IV.1 - Mattingly H.andSydenham E. A. 1936, (repr. 1962)

The Roman Imperial Coinage, IV/1, Pertinax to Geta, London: Spink \& Son Ltd.

\section{RIC V.1 - Webb P. H. 1968}

The Roman Imperial Coinage, V. 1, London: Spink \& Son Ltd.

\section{RIC V.2 - Webb P. H. 1972}

The Roman Imperial Coinage, V.2, London: Spink \& Son Ltd.

RRC I - Crawford M. H. 1974

Roman Republican Coinage I, London: Cambridge University Press.

SHA - 1921-1932

The Scriptores Historiae Augustae. Vol. I-III. Translated by David Magie. Loeb Classical Library. Cambridge Mass., London: Harvard University Press.

Tacit Ann. = Tacitus, P. C. 1970

Анали, (пр.) Љ. Црепајац, Београд: Српска књижевна задруга.

Vojvoda, M. and Tapavički-Ilić, M. 2012 Inheriting the Throne during the Principate in the Light of Reverse Images on Roman Imperial Coins, Arheologija i prirodne nauke 7 (2011): 303-328.

\section{Wallace-Hadrill A. 1981}

The Emperor and His Virtues, Historia: Zeitschriftfür Alte Geschichte, Vol. 30, No. 3 (1981): 298-323. 


\section{REZIME KONCEPCIJA PROVIDENTIA DEORUMU OKVIRU KULTA CARSKE LIČNOSTI I PROPA- GANDE NA RIMSKOM CARSKOM NOVCU TOKOM PRINCIPATA}

KLJUČNE REČI: RIMSKO CARSTVO, NOVAC, REVERSNE PREDSTAVE, PROPAGANDA, KULT CARSKE LIČNOSTI, PROVIDENTIA DEORUM.

Institucija kulta carske ličnosti, kakvu poznajemo tokom Principata, svoje početke ima u 1.v.s.e., a važan momenat u njenom razvoju predstavlja deifikacija Cezara 42.g.s.e. Težnja Cezara u naglašavanju porekla roda Julijevaca od Venere, bio je zapravo jedan od načina kako bi opravdao svoj položaj, ali istovremeno predstavlja i začetke razvoja carskog kulta. Oktavijan je, potom, mudro osmislio i utemeljio novo državno uređenje Principat - i to u okviru postojećih republikanskih institucija. Tokom njegove vladavine carski kult je postepeno uspostavljan i vremenom institucionalizovan.

Avgust je uspeo da uspostavi carski kult preko koga je dosegao prepoznavanje njegove božanske prirode nakon smrti. Modifikujući koncepciju Genija i prihvatanjem da se odaju počasti njegovom ličnom Geniju, bio je način da javnost nezvanično obožava njegovu potencijalnu božansku prirodu. Istovremeno se, u velikoj meri, oslanjao i na model kulta Aleksandra Makedonskog, što je dovelo do postepenog razvoja carskog kulta kao jedinstvene rimske institucije. U okviru na ovaj način ustanovljenog carskog kulta, razvijala se istovremeno i koncepcija providentia. Pisci i pesnici Avgustovog vremena daju veliki naglasak prepoznavanju božije volje u činjenici da su dobili takvog spasioca i vladara.

U svrhu širenja carskog kulta vešto i obimno je korišćena propaganda manifestovana kroz različite medije: javni spomenici i natpisi, oltari i hramovi u čast careva, njihovi sveštenički kolegiji i festivali, književnici angažovani u državnoj služ- bi, itd. Međutim, carevi su visok nivo opšte političke propagande, pa i segmenta vezanog za carski kult, ostvarivali koristeći novac. Jedan od aspekata propagande ostvarivan putem reversnih predstava na novcu, jesu i motivi sa pratećom legendom PROVIDENTIA DEORVM. Korisnicima je trebalo preneti poruku da je vlast i upravljanje državom u dobrobit svih građana, caru dato po volji i promišljenošću bogova, u prvom redu Jupitera. Iz ove osnovne propagandne poruke koncepcije providentia deorum, proizilazi i njena povezanost sa problemom nasleđivanja u Principatu.

Počev od Domicijana, preko Trajana, u vreme Hadrijana se jasno fokusira koncepcija providentia deourum, koja izražava višeslojnu povezanost cara sa bogovima. Ne samo da car uživa zaštitu božanstava, u prvom redu Jupitera, nego, što je još važnije, da je od njega izabran da vlada. Kreirana je slika aktuelnog cara, koji je to postao zahvaljujući promišljenosti samog Jupitera. Ova činjenica, skrivena u slojevitosti značenja pomenutih predstava cara i Jupitera, eksplicitno je prikazana na novcu Hadrijana u sceni gde mu Jupiterov orao donosi i predaje skiptar uz legendu providentia deorum. Isto značenje imaju i scene u kovanjima od Hadrijana do Proba, u kojima carevi primaju od Jupitera glob, kao simbol svetske vladavine. Sa izvesnom stabilizacijom u državi u vreme Aurelijana, došlo je i do promena u pogledu pokroviteljstva vrhovnog božanstva. Uvođenje kulta Nepobedivog Sola odrazilo se na motive reversnih predstava uz legendu PROVIDENTIA DEORVM, na kojima se pojavljuje personifikacija u vojnom aspektu, sa insignijama, u pratnji Sola Inviktusa. Istorijske okolnosti dovele su do promena u svim društvenim sferama, pa i u religiji, kojima se nužno prilagodjavala i propaganda carskog kulta, a u okviru toga i koncepcija providentia deorum. 